\title{
Pengaruh Beban Pajak Tangguhan dan Mekanisme Corporate Governance Pada Manajemen Laba
}

\author{
I Wayan Andika ${ }^{1}$ \\ I G.A.M. Asri Dwija Putri
}

${ }^{1}$ Fakultas Ekonomi dan Bisnis Universitas Udayana (Unud), Bali - Indonesia
email: andikawipra @ gmail.com/Telp: 085737530934
${ }^{2}$ Fakultas Ekonomi dan Bisnis Universitas Udayana (Unud), Bali - Indonesia

\begin{abstract}
ABSTRAK
Kontrak antara manajemen dan pihak pemegang saham tidak jarang menimbulkan konflik mengingat informasi lebih banyak dimiliki oleh manajemen yang dapat bertindak opurtunistik dengan tindakan manajemen laba. Beban pajak tanguhan dapat digunakan untuk mendeteksi manajemen laba. Penerapan Good Corporate Governance (GCG) merupakan kewajiban perusahaan agar terciptanya keselarasan antara kepentingan agen dan prinsipal. Penelitian ini bertujuan untuk memperoleh bukti empiris pengaruh beban pajak tangguhan dan mekanisme CG yaitu dewan direksi, dewan komisaris independen, komite audit independen, kepemilikan institusional dan kepemilikan manajerial. Populasi perusahaan manufaktur yang terdaftar di Bursa Efek Indonesia. Penentuan sampel menggunakan teknik purposive sampling. Regresi linier berganda sebagai alat analisis data. Berdasarkan hasil analisis ditemukan bahwa beban pajak tangguhan dewan direksi, dewan komisaris independen, komite audit independen, kepemilikan institusional dan kepemilikan manajerial berpengaruh positif signifikan pada manajemen laba.

Kata kunci: Manajemen laba, beban pajak tangguhan, mekanisme corporate governance.
\end{abstract}

\footnotetext{
ABSTRACT

Contracts between the management and the shareholder are not uncommon to cause conflict because more information is owned by management that can act opportunistically with earnings management. The deferred tax expense can be used to detect earnings management. Implementation of Good Corporate Governance $(G C G)$ is a company's obligation to create alignment between the interests of agents and principals. This study aims to obtain empirical evidence of the effect of deferred tax expense and CG mechanisms: boards of directors, independent board of commissioners, independent audit committees, institutional ownership and managerial ownership. The population of manufacturing companies listed on the Indonesia Stock Exchan. Determination of sample using purposive sampling technique. Multiple linear regression as data analysis instrument. Based on the discussion of the results of the study prove that the deferred tax expense, independent board of commissioners, independent audit committees, institutional ownership and managerial ownership have a significant positively affect earnings management.

Keywords: Earnings management, deferred tax expense, corporate governance mechanism.
} 


\section{PENDAHULUAN}

Teori keagenan menjelaskan hubungan dua atau lebih orang dimana ada pihak agen dan prinsipal yang dituangkan dalam sebuah kontrak. Tujuan dari diadakannya kontrak ini adalah untuk menciptakan kinerja yang efisien dengan berbagai syarat. Ketika dalam pelaksanaannya ternyata syarat tersebut tidak terpenuhi maka timbullah konflik yang disebabkan oleh beberapa hal. Jensen dan Mecling (1976) menyatakan manajer (agent) secara moral bertanggungjawab atas keuntungan para pemilik (principal) dan sebagai imbalannya manajer dapat memperoleh kompensasi sesuai dengan kontrak.

Manajemen ingin memperoleh bonus yang maksimal atas kinerja yang dilakukannya, sedangkan pemegang saham menginginkan return yang maksimal dan dalam waktu cepat dapat menerima hasil dari investasi yang dilakukannya. Adanya ketidakseimbangan informasi antara manajemen dengan pemegang saham mengingat informasi lebih dimiliki manajemen disebut dengan asimetri informasi. Asimetri informasi antara manajemen dengan pemilik dapat memberikan kesempatan kepada manajer untuk melakukan manajemen laba (earning management). Pemegang saham akan sulit mengontrol secara efektif tindakan yang dilakukan manajemen karena informasi yang dimilikinya sedikit. Kepentingan antara manajemen dan pemegang saham dapat menyebabkan suboptimal keputusan manajemen (Uwuigbe et al., 2014).

Kinerja manajer diukur berdasarkan informasi laba, sehingga manajer selaku pengelola perusahaan akan cenderung melakukan tindakan yang menyimpang. Manajemen memaksimalkan keinginannya dengan cenderung 
melakukan tindakan moral hazard dan mengorbankan kepentingan pemegang saham menimbulkan konflik keagenan (Putri, 2012).

Penyusunan laporan keuangan di Indonesia berpedoman pada Peraturan Perpajakan dan PSAK yaitu laporan keuangan berdasarkan prinsip akuntansi berterima yang umum dan yang dihitung berdasarkan pedoman perpajakan yang berlaku (Tunjung, 2015). Hal ini memberikan manajemen fleksibilitas dalam meyusun laporan keuangan yang diatur dalam Pedoman Standar Akuntansi Keuangan (PSAK) No.1 tentang penyajian laporan keuangan dengan pendekatan akrual (accrual basis).

Manajemen berusaha menampilkan hasil kinerja keuangannya dengan baik untuk pemegang saham dan pengguna eksternal lainnya. Disisi lain manajemen perusahaan untuk keperluan pajak ingin memperkecil laba kena pajak yang akan dilaporkannya (Ettredge et al., 2008 dalam Tunjung, 2015). Sehingga memanipulasi laba merupakan hal yang dapat dijadikan untuk meninggikan laporan keuangan namun merendahkan laba untuk pelaporan pajaknya. Beban pajak tangguhan dijadikan suatu ukuran dalam mendeteksi manajemen laba, karena kebijakan akrual yaitu cara yang dilakukan manajer memanipulasi laba dan refleksi dari kebijakan tersebut adalah beban pajak tangguhan dari besaran beda waktu yang dihasilkan. Pengakuan pajak tangguhan bisa membawa akibat terhadap berkurangnya laba bersih jika ada pengakuan beban pajak tangguhan. Sebaliknya juga bisa berakibat berkurangnya rugi bersih jika ada pengakuan manfaat pajak tangguhan (Suandy, 2011:99). 
Good corporate governance yang diterapkan perusahaan memberikan keyakinan bagi pengguna informasi keuangan perusahaan bahwa laporan tersebut terbebas dari pelanggaran (fraud) (Prastiti, 2013). Konsep GCG menekankan dua hal, pemegang saham mempunyai hak memperoleh informasi yang benar (akurat), tepat pada waktunya dan semua informasi mengenai kinerja perusahaan, stakeholder dan kepemilikan wajib diungkapkan perusahaan dengan transparan, akurat dan tepat waktu (Rahadi, 2014).

Pemegang saham bergantung pada Kemampuan komite audit dan dewan komisaris diharapkan oleh pemegang saham untuk memonitoring kinerja manajemen Alzoubi \& Selamat (2012). Dalam Buku Pedoman Komite Nasional Kebijakan Governance KNKG (2006) prinsip dasar kepengurusan perseroan terbatas di Indonesia menganut sistem dua badan (two-board system) yaitu dewan komisaris dan direksi yang mempunyai wewenang dan tanggung jawab yang jelas sesuai dengan fungsinya masing-masing.

Mekanisme gcg yang lainnya yaitu struktur kepemilikan yang terdiri dari kepemilikan manajerial dan kepemilikan institusional. Konsentrasi kepemilikan institusional merupakan saham perusahaan yang dimiliki oleh institusi atau lembaga. Kepemilikan institusional mencerminkan kemampuan pemegang saham institusional mempengaruhi kinerja manajemen perusahaan yang erat kaitannya dengan pelaporan keuangan (Prabaningrat, 2015). Investor institusional lebih aktif dalam pengawasan karena investor institusional cenderung berinvestasi dalam jumlah yang sangat besar (Wiranata dan Nugrahanti, 2013). Kepemilikan manajerial merupakan persentase saham yang dimiliki oleh direktur dan 
komisaris. Adanya kepemilikan saham manajerial, manajer cenderung ingin menyelaraskan kepentingannya dengan pemegang saham, sehingga manajemen laba yang dilakukan karena kepentingan pribadi menjadi berkurang (Wiryadi, 2013).

Berdasarkan penjelasan latar belakang, fenomena manajemen laba menarik perhatian peneliti untuk meneliti kembali tentang pengaruh beban pajak tangguhan, dewan direksi, dewan komisaris independen, komite audit independen, kepemilikan institusional dan kepemilikan manajerial pada manajemen laba. Rumusan masalah yang dapat diajukan yaitu apakah beban pajak tangguhan, dewan direksi, dewan komisaris independen, komite audit independen, kepemilikan institusional dan kepemilikan manajerial berpengaruh pada manajemen laba ?

Hasil penelitian juga diharapkan dapat mendukung pengembangan ilmu akuntansi yang berkaitan dengan beban pajak tangguhan, dewan direksi, dewan komisaris independen, komite audit, kepemilikan institusional dan kepemilikan manajerial pada manjemen laba serta mendukung teori keagenan dan teori akuntansi positif. Teori keagenan merupakan dasar yang digunakan untuk memahami hubungan antara manajer (agent) dengan pemegang sahan (principal). Hubungan manajer dengan pemegang saham merupakan sebuah kontrak yang disebut dengan hubungan keagenan (Jensen dan Meckling, 1976).

Manajer diberikan hak oleh pemegang saham untuk menjalankan perusahaannya dengan harapan mampu mengelola dan menghasilkan laporan keuangan yang baik. Asimetri informasi antara manajemen (agent) dengan 
pemegang saham (principal) memberikan peluang kepada manajemen untuk melakukan manajemen laba (earning manajement). Menurut Watts and Zimmerman (1986) menyatakan tiga hipotesis PAT (Positive Accounting Theory) yang dijadikan dasar pemahaman tindakan manajemen laba, yaitu pertama, the bonus plan hypothesis. Perusahaan memilih metode akuntansi meningkatkan laba saat ini dengan menggeser laba masa depan merupakan salah satu cara untuk memenuhi rencana pemberian bonus dari perusahaan.

Kedua, the debt to equity hypothesis (Hipotesis perjanjian utang), metode akuntansi dipilih dengan meningkatkan laba dilakukan ketika perusahaan memiliki rasio debt to equity tinggi. Ketiga, the political cost hypothesis (Hipotesis kos politik), metode akuntansi dimana menangguhkan laba dilaporkan periode sekarang ke periode masa mendatang dipilih perusahaan besar yang memiliki biaya politik tinggi. Manajemen laba adalah kebijakan akuntansi yang dipilih manajer atau tindakan lainnya termasuk peramalan penghasilan sukarela, pengungkapan sukarela dan estimasi akrual untuk mempengaruhi pendapatan secara sengaja (Man, 2013). Tingkat implementasi komponen tata kelola perusahaan seperti transparasi data keuangan, dewan direksi, struktur kepemilikan, tanggungjawab sosial dan komite audit diperkirakan mampu mengurangi manajemen laba yang kurang baik (Al-Hafi, 2016).

Menurut Scott (2006: 344) pemahaman tentang manajemen laba dibedakan menjadi dua. Pertama, manajemen laba karena perilaku oportunis manajer untuk memaksimalkan utilitasnya dalam menghadapi kontrak kompensasi, kontrak utang, dan political costs (oportunistic Earnings 
Management). Kedua, manajemen laba dipandang dari perspektif efficient contracting (Efficient Earnings Management), memberi manajer suatu fleksibilitas untuk melindungi diri pihak manajemen dan perusahaan untuk mengantisipasi kejadian-kejadian tak terduga untuk keuntungan pihak-pihak yang termasuk didalam kontrak. Terdapat empat bentuk manajemen laba yang dapat dilakukan oleh manajer seperti (1) Taking a bath, (2) Income maximization, (3) Income minimization, (4) Income smoothing. Motivasi manajemen laba menurut Scott (2009) disebabkan oleh beberapa hal, yaitu: (1) bonus purposes, (2) motivasi kontrak pinjaman; (3) political motivation, (4) taxation motivation; (5) pergantian CEO, (6) initial public offering (IPO), (7) pentingnya memberi informasi kepada investor.

Beban pajak tangguhan jika dilihat dari hasil koreksi fiskal yaitu koreksi negative dikatakan mampu mendeteksi praktik manajemen laba (Negara, 2017). Ulfah (2013) dan Budiman (2013) menemukan beban pajak tangguhan berpengaruh terhadap adanya indikasi praktik manajemen laba. Sedangkan Negara (2013) menemukan beban pajak tangguhan berpengaruh positif pada manajemen laba, dimana ketika nilai beban pajak tangguhan semain tinggi akan mengakibatkan profitabilitas perusahaan melakukan manajemen laba juga semakin tinggi. Berdasarkan uraian tersebut, maka dapat dikembangkan hipotesis sebagai berikut.

$\mathrm{H}_{1}$ : Beban pajak tangguhan berpengaruh positif pada manajemen laba.

$\mathrm{H}_{2} \quad$ : Dewan direksi berpengaruh positif pada manajemen laba. 
Tindakan manajemen laba dapat diminimalisir bahwa dewan komisaris independen menjamin pelaksanaan kebijakan manajemen laba yang diberlakukan pada perusahaan. Hasil penelitian Sari dan Putri (2014), Reviani (2012) menunjukkan bahwa komposisi dewan komisaris independen berpengaruh negatif pada manajemen laba. Dimana komposisi dewan komisaris independen berdampak pada manajemen laba oleh perusahaan yang komposisinya tepat Berdasarkan uraian tersebut, maka dapat dikembangkan hipotesis sebagai berikut. $\mathrm{H}_{3}$ : dewan komisaris independen berpengaruh negatif pada manajemen laba. Keindependenan komite audit dalam melaksanakan tugas dan tanggungjawabnya, berfungsi agar tidak terjadi benturan kepentingan antara pihak-pihak yang terkait dalam perusahaan dan Klien (2002) menyatakan pengurangan jumlah komite audit dapat meningkatkan akrual abnormal yang besar. Sari dan Putri (2014) menemukan bahwa komite audit berpengaruh negatif terhadap manajemen laba namun tidak signifikan. Hadirnya komite audit di perusahaan mampu meningkatkan pengawasan pada pelaporan keuangan perusahaan yang dibuat manajer. Berdasarkan uraian tersebut, maka dapat dikembangkan hipotesis sebagai berikut.

$\mathrm{H}_{4} \quad$ : komite audit independen berpengaruh negatif pada manajemen laba.

Kepemilikan institusional mampu mengendalikan pihak manajemen dari funsi monitoring secara efektif sehingga mampu meminimalisir tindakan menyimpang dari manajemen. Mahadewi (2017) yang menemukan kepemilikan institusional berpengaruh negatif pada manajemen laba, kepemilikan saham 
institusional yang tinggi mampu mengurangi manajemen laba pada suatu perusahaan.

Berdasarkan uraian tersebut, maka dapat dikembangkan hipotesis sebagai berikut. $\mathrm{H}_{5} \quad$ : Kepemilikan institusional berpengaruh negatif pada manajemen laba. Kepemilikan manajerial sebagai presentase saham yang dimiliki oleh manajemen yang secara aktif ikut andil mengambil keputusan perusahaan yang terdiri dari komisaris dan direksi (Mahariana, 2014). Sari (2014) dan mahariana (2014), Kusumawardani (2012) dalam penelitiannya menemukan kepemilikan manajerial berpengaruh negatif terhadap manajemen laba yang menunjukkan kepemilikan manajerial mampu menurunkan tindakan manajemen laba, semakin tinggi kepemilikan manajerial maka akrual diskresioner perusahaan akan mengalami penurunan.

Berdasarkan uraian tersebut, maka dapat dikembangkan hipotesis sebagai berikut. $\mathrm{H}_{6} \quad$ : Kepemilikan manajerial berpengaruh negatif pada manajemen laba.

\section{METODE PENELITIAN}

Penelitian ini menggunakan pendekatan kuantitatif yang berbentuk asosiatif. Pendekatan kuantitatif adalah metode yang digunakan untuk meneliti populasi atau sampel tertentu yang bertujuan untuk menguji hipotesis yang telah ditentukan (Sugiyono, 2014:13). Penelitian ini dilakukan di Bursa Efek Indonesia (BEI). Ruag lingkup perusahaan manufaktur yang terdaftar di BEI tahun 2013-2016. Data laporan keuangan diperoleh dari situs resmi BEI yaitu www.idx.co.id dan nama-nama perusahaan diperoleh dari situs www.sahamok.com. 
Obyek penelitian adalah manajemen laba (Y) dari perusahaan manufaktur yang terdaftar di BEI tahun 2013-2016 yang dipengaruhi oleh beban pajak tangguhan $\left(\mathrm{X}_{1}\right)$ dan mekanisme corporate governance yang diproksikan dengan dewan direksi $\left(\mathrm{X}_{2}\right)$, dewan komisaris independen (X3), komite audit independen $\left(\mathrm{X}_{4}\right)$, kepemilikan institusional $\left(\mathrm{X}_{5}\right)$ dan kepemilikan manajerial (X6).

Manajemen laba suatu kondisi dimana manajemen melakukan intervensi dalam proses penyusunan laporan keuangan untuk pihak eksternal dalam bentuk meratakan, menaikkan dan menurunkan pelaporan laba (Saraswati, 2016). Healy (1985) meneliti akrual manajemen yang dideteksi digunakan sebagai alat manajemen laba untuk meningkatkan insentif manajemen yang berupa bonus. Dalam penelitian ini manajemen laba diukur menggunakan Discretionary Accrual (DA). Modified Jones Model yang dikembangkan oleh Dechow et al. (1995). Modified Jones model dianggap sebagai alat perhitungan yang paling ampuh untuk mendeteksi adanya praktik manajemen laba (Islam et al., 2011).

Pengukuran DA, terlebih dahulu dihitung total accrual. Total accrual dikelompokkan menjadi komponen Discretoinary dan Nondiscretionary dengan tahapan:

Mengukur total Accrual menggunakan model Jones modifikasian (Susanto dan Christiawan, 2016), yaitu:

$\mathrm{TA}_{\mathrm{it}}=\mathrm{NI}_{\mathrm{it}}-\mathrm{CF} 0_{\mathrm{i}}$

Keterangan:

$\mathrm{TA}_{\mathrm{it}} \quad$ : Total Akrual Perusahaan i pada periode ke $\mathrm{t}$

$\mathrm{NI}_{\mathrm{it}}$ : Laba Bersih Perusahaan i pada periode ke $\mathrm{t}$

$\mathrm{CFO}_{\text {it }}$ : Aliran Kas dari Aktivitas Operasi Perusahaan I pada periode ke $\mathrm{t}$ 
Menghitung koefisien regresi (Dechow et al., 1995)

$\mathrm{TA}_{\mathrm{it}} / \mathrm{A}_{\mathrm{it}-1}=\beta_{1}\left(1 / \mathrm{A}_{\mathrm{it}-1}\right)+\beta_{2}\left(\Delta \mathrm{REV}_{\mathrm{it}} / \mathrm{A}_{\mathrm{it}-1} 1-\Delta \mathrm{REC}_{\mathrm{it}} / \mathrm{A}_{\mathrm{it}-1}\right)+\beta_{3}\left(\mathrm{PPE}_{\mathrm{it}} / \mathrm{A}_{\mathrm{it}-1}\right)+\varepsilon_{\mathrm{it}}$

Keterangan:

$\mathrm{TA}_{\mathrm{it}} \mathrm{t} \quad$ : Total Accrual perusahaan i pada periode $\mathrm{t}$

$\mathrm{A}_{\mathrm{it}-1} \quad$ : Total asset perusahaan i pada akhir tahun t-1

$\triangle \mathrm{REV}_{\mathrm{it}} \quad$ : Perubahan Pendapatan Perusahaan i pada periode ke $\mathrm{t}$

$\triangle \mathrm{REC}_{\mathrm{it}} \quad$ : Perubahan Piutang Perusahaan i pada periode ke $\mathrm{t}$

$\mathrm{PPE}_{\mathrm{it}} \quad:$ Aset Tetap Perusahaan i pada periode ke $\mathrm{t}$

$\varepsilon \quad:$ error tern perusahaan I pada periode ke $\mathrm{t}$

$\beta \quad$ : Koefisien regresi

Menghitung Nondiscretionary Accrual model (NDA) adalah sebagai berikut:

$\mathrm{NDA}_{i t}=\beta_{1}\left(1 / \mathrm{A}_{\mathrm{it}-1}\right)+\beta_{2}\left(\Delta \mathrm{REV}_{\mathrm{it}} / \mathrm{A}_{\mathrm{it}-1}-\Delta \mathrm{REC}_{\mathrm{it}} / \mathrm{A}_{\mathrm{it}-1}\right)+\beta_{3}\left(\mathrm{PPE}_{\mathrm{it}} / \mathrm{A}_{\mathrm{it}-1}\right)$

Keterangan:

$\mathrm{NDA}_{\mathrm{it}} \quad:$ Nondiscretionary Accrual perusahaan i pada periode $\mathrm{t}$

$\mathrm{A}_{\mathrm{it}-1} \quad$ : Total asset perusahaan i pada akhir tahun $\mathrm{t}-1$

$\triangle \mathrm{REV}_{\mathrm{it}} \quad$ : Perubahan Pendapatan Perusahaan i pada periode ke $\mathrm{t}$

$\triangle \mathrm{REC}_{\mathrm{it}} \quad$ : Perubahan Piutang Perusahaan i pada periode ke $\mathrm{t}$

$\mathrm{PPE}_{\mathrm{it}} \quad:$ Aset Tetap Perusahaan i pada periode ke $\mathrm{t}$

$\varepsilon \quad:$ error tern perusahaan I pada periode ke $\mathrm{t}$

$\beta \quad$ : Koefisien regresi

Menghitung Discretionary Accrual (DA) adalah sebagai berikut:

$\mathrm{DA}_{\mathrm{it}}=\left(\mathrm{TA}_{\mathrm{it}} / \mathrm{A}_{\mathrm{it}-1}\right)-\mathrm{NDA}_{\mathrm{it}}$

Keterangan:

$\mathrm{DA}_{\mathrm{it}} \quad$ : Discretionary Accrual perusahaan i pada periode $\mathrm{t}$

$\mathrm{TA}_{\mathrm{it}}$ : Total Akrual Perusahaan i pada period eke $\mathrm{t}$

$\mathrm{A}_{\mathrm{it}} \quad$ : Total Aset Perusahaan i pada periode t-1

NDA $_{i t}$ : Non Discretionary Accruals Perusahaan i pada periode ke t

Perhitungan beban pajak tangguhan mengacu pada penelitian Amanda

(2015) yaitu menggunakan indikator rasio beban pajak tangguhan dengan total aktiva.

$$
B P T=\frac{\text { Beban Pajak Tanggu han } t}{\text { Total Aset } t-1}
$$


Ukuran dewan direksi diukur dengan menggunakan indikator jumlah anggota dewan direksi dalam suatu perusahaan mengacu pada penelitian Oktavani (2016).

$$
D D=J u m l a h \text { seluruh dewan direksi }
$$

Prastiti (2013) proporsi dewan komisaris independen (KInd) diukur dengan menggunakan indikator Persentase anggota dewan komisaris yang berasal dari luar perusahaan dari seluruh anggota dewan komisaris perusahaan.

$$
\text { KInd }=\frac{\text { Jumla } h \text { Komisaris Independen }}{\text { Total anggota komisaris }} \times 100 \%
$$

Menurut (Restie, 2010 dalam Reviani, 2012), keberadaan komite audit independen (KA) diukur dengan rumus:

$$
K A=\frac{\text { Anggota komite audit dari luar }}{\text { Total ang gota komite audit }} \times 100 \%
$$

Sari (2014) menghitung KI dengan indikator kepemilikan institusional adalah Persentase jumlah saham yang dimiliki pihak institusional dari seluruh modal saham perusahaan.

$$
K I=\frac{\text { Jumla } h \text { saham yang dimiliki institusional }}{\text { Total saham yang dimiliki perusa haan }} \times 100 \%
$$

Kepemilikan manajerial dapat diukur dengan presentase jumlah saham yang dimiliki oleh manajemen dari seluruh modal saham perusahaan (Apriada, 2013).

$$
K M=\frac{\text { Jumla h saham yang dimiliki manajerial }}{\text { Total saham yang dimiliki perusa haan }} \times 100 \%
$$

Populasi dalam penelitian ini adalah perusahaan manufaktur yang terdaftar di Bursa Efek Indonesia tahun 2013-2016. Sampel ditentukan berdasarkan pada teknik purposive sampling. Purposive sampling adalah teknik pengambilan sampel dengan pertimbangan atau dengan kriteria tertentu (Sugiyono, 2014:122). 
Kriteria yang dipertimbangkan dalam pengambilan sampel adalah sebagai berikut : (1) Perusahaan yang terdaftar di (BEI) secara berturut-turut pada periode pengamatan 2013-2016, (2) Perusahaan yang menerbitkan laporan keuangan akhir periode 31 Desember, (3) Perusahaan yang menampilkan laporan keuangan dalam mata uang rupiah, (4) Data perusahaan yang lengkap mencantumkan dan memiliki beban pajak tangguhan, dewan direksi, dewan komisaris independen, komite audit independen, kepemilikan institusional dan kepemilikan manajerial.

Metode pengumpulan data dalam penelitian ini dilakukan dengan metode dokumentasi. Jenis data yang digunakan adalah data kuantitatif dan data kualitatif dan sumber data yaitu data sekunder. Penelitian ini menggunakan analisis regresi berganda dengan program SPSS. Model regresi dirumuskan dengan persamaan berikut :

$Y=\alpha+\beta_{1} X_{1}+\beta_{2} X_{2}+\beta_{3} X_{3}+\beta_{4} X_{4}+\beta_{5} X_{5+} \beta_{6} X_{6}$

Keterangan:

$\begin{array}{ll}\mathrm{Y} & =\text { Variabel terikat (Manajemen Laba) } \\ \alpha & =\text { Konstanta } \\ \beta_{1}, \beta_{2}, \beta_{3}, \beta_{4}, \beta_{5}, \beta_{6} & =\text { koefisien regresi untuk } \mathrm{X}_{1}, \mathrm{X}_{2}, \mathrm{X}_{3}, \mathrm{X}_{4}, \mathrm{X}_{5}, \mathrm{X}_{6} \\ \mathrm{X}_{1} & =\text { Variabel bebas ( beban pajak tangguhan) } \\ \mathrm{X}_{2} & =\text { Variabel bebas ( dewan direksi) } \\ \mathrm{X}_{3} & =\text { Variabel bebas ( dewan komisaris independen) } \\ \mathrm{X}_{4} & =\text { Variabel bebas ( komite audit independen) } \\ \mathrm{X}_{5} & =\text { Variabel bebas (kepemilikan institusional) } \\ \mathrm{X}_{6} & =\text { Variabel bebas (kepemilikan manajerial) }\end{array}$

Sebelum dilakukan analisis regresi berganda, dilakukan uji asumsi klasik. Model regresi harus terbebas dari masalah multikolinieritas, heteroskedastisitas, autokorelasi dan normalitas data. Setelah terbebas dari gejala asumsi klasik dilakukan analisis regresi berganda, selanjutkan uji kelayakan model (Uji F), dilanjutkan dengan uji hipotesis (Uji t) untuk menjawab hipotesis penelitian 
dengan tingkat signifikansi 0.05 , dan terakhir koefisien determinasi $\left(\mathrm{R}^{2}\right)$ untuk melihat keeratan hubungan antara variabel independen dan variabel dependen.

\section{HASIL DAN PEMBAHASAN}

Purposive sampling merupakan teknik memilih perusahaan sesuai dengan kriteria yang telah ditetapkan. Terdapat 144 perusahaan sektor manufaktur yang terdaftar di Bursa Efek Indonesia dari tahun 2013-2016, 24 perusahaan sesuai dengan kriteria yang ditentukan sehingga jumlah pengamatan yang digunakan sebanyak 96 pengamatan.

Tabel 1.

Statistik Deskriptif

\begin{tabular}{lrrrrr}
\hline & & & & \multicolumn{1}{c}{$\begin{array}{c}\text { Std. } \\
\text { Deviation }\end{array}$} \\
\hline Manajemen Laba & Minimum & Maximum & \multicolumn{1}{c}{ Mean } & \multicolumn{1}{c}{ De, } \\
Beban Pajak Tangguhan (BPT) & 96 & $-0,5311$ & 0,4496 & 0,026329 & 0,1283259 \\
& & $-0,1515$ & 0,0591 & $-0,001879$ & 0,0193512 \\
Dewan Direksi (DD) & 96 & & & & \\
Dewan Komisaris Independen & 96 & 0,3333 & 0,5000 & 0,380338 & 0,0684867 \\
(DKind) & & & & & \\
Komite Audit Independen (KA) & 96 & 0,3333 & 0,7500 & 0,638916 & 0,0885941 \\
Kepemilikan Institusional (KI) & 96 & 0,0541 & 0,9800 & 0,699599 & 0,1875716 \\
Kepemilikan Manajerial (KM) & 96 & 0,0000 & 0,5711 & 0,055353 & 0,0862041 \\
Valid N (listwise) & 96 & & & & \\
\hline
\end{tabular}

Sumber : Data diolah 2017

Hasil uji statistik deskriptif data penelitian menunjukkan, rata-rata (mean) manajemen laba sebesar 0,0263, Variabel independen beban pajak tangguhan (x1) memiliki rata-rata (mean) sebesar -0,0018. Variabel dewan direksi (x2) memiliki nilai rata-rata (mean) sebesar 4,63 menunjukkan dalam pengamatan rata-rata jumlah dewan direksi 4,63. Variabel dewan komisaris independen (x3) memiliki nilai rata-rata (mean) sebesar 0,3803 menunjukkan rata-rata anggota dewan komisaris independen sebesar 38,03 persen. Variabel komite audit independen (x4) memiliki rata-rata (mean) sebesar 0,6389 berarti jumlah komite audit 
independen di dalam pengamatan sebesar 63,89 persen, variabel kepemilikan institusional (x5) memiliki nilai rata-rata (mean) sebesar 0,699 menunjukkan ratarata kepemilikan institusional dalam pengamatan sebesar 69,9 persen. Variabel kepemilikan manajerial (x6) memiliki nilai rata-rata (mean) sebesar 0,0553 menunjukkan rata-rata kepemilikan manajerial dalam pengamatan sebesar 5,53 persen.

Uji asumsi klasik terdiri dari uji normalitas, uji autokorelasi, uji multikolinearitas, dan uji heteroskedastisitas. Uji normalitas dilakukan dengan menggunakan uji Kolmogorov-Smirnov, yaitu jika koefisien Asymp. Sig (2-tailed) lebih besar dari $\alpha=0.05$ (5\%) maka dapat dikatakan bahwa data populasi memiliki distribusi normal. Hasil uji normalitas dalam penelitian ini menunjukkan nilai sig 0,421 > alpha 0.05 sehingga asumsi normalitas telah terpenuhi.

Uji multikolinearitas untuk menguji ada tidaknya korelasi antar variabel bebas pada model regresi, dapat dilihat dari nilai tolerance atau variance inflation factor (VIF). Jika nilai tolerance $>10 \%$ atau VIF $<10$, dapat disimpulkan tidak ada multikolinearitas. Hasil penelitian menunjukkan nilai tolerance dan VIF dari semua variable memiliki nilai tolerance untuk setiap variabel lebih besar dari $10 \%$ dan nilai VIF lebih kecil dari 10 sehingga model persamaan regresi bebas dari multikolinearitas.

Uji autokorelasi dilakukan untuk melacak adanya korelasi atau pengaruh residual dari pengamatan sebelumnya dalam suatu model regresi. Uji autokorelasi dilakukan dengan menggunakan uji Durbin-Watson (DW-test). Nilai DW 2,047, bila dibandingkan dengan nilai tabel signifikansi 5\%, jumlah sampel 96 (n) dan 
jumlah variabel independen $(K=6)$ diperoleh nilai du 1,8023. Nilai DW 2,047 lebih besar dari batas atas (du) yakni 1,8023 dan kurang dari (4-du) 4-1,8023= 2,197, maka dapat disimpulkan bahwa tidak terdapat autokorelasi .

Uji heteroskedastisitas dilakukan untuk mengetahui ketidaksamaan varian pada model regresi. Penelitian ini menggunakan model glejser untuk mendeteksi ada tidaknya heterokedastisitas. Nilai signifikansi dari variabel beban pajak tangguhan, dewan direksi, dewan komisaris independen, komite audit independen, kepemilikan institusional dan kepemilikan manajerial masing-masing sebesar 0,$198 ; 0,996 ; 0,770 ; 0,314 ; 0,725$ dan 0,224 lebih besar dari alpha 0,05 sehingga model regresi tidak mengandung heteroskedastisitas.

Berdasarkan hasil analisis regresi linier berganda seperti yang disajikan pada Tabel 2, maka persamaan strukturalnya adalah sebagai berikut :

$$
\begin{aligned}
& \mathrm{Y}=0,269+0,127 \mathrm{X} 1+0,212 \mathrm{X} 2+0,142 \mathrm{X} 3+0,133 \mathrm{X} 4+0,131 \mathrm{X} 5+ \\
& 0,236 \mathrm{X} 6+\mathrm{e}
\end{aligned}
$$

Tabel 2.

Hasil Analisis Regresi Linier Berganda

\begin{tabular}{lcc}
\hline \multicolumn{1}{c}{ Variabel } & $\begin{array}{c}\text { Nilai Koefisien } \\
\text { Regresi }\end{array}$ & Signifikansi \\
\hline Constant & 0,269 & 0,032 \\
Beban Pajak Tangguhan $\left(\mathrm{X}_{1}\right)$ & 0,127 & 0,017 \\
Dewan Direksi $\left(\mathrm{X}_{2}\right)$ & 0,212 & 0,000 \\
Dewan Komisaris Independen $\left(\mathrm{X}_{3}\right)$ & 0,142 & 0,003 \\
Komite Audit Independen $\left(\mathrm{X}_{4}\right)$ & 0,133 & 0,003 \\
Kepemilikan Institusional $\left(\mathrm{X}_{5}\right)$ & 0,131 & 0,002 \\
Kepemilikan Manajerial $\left(\mathrm{X}_{6}\right)$ & 0,236 & 0,000 \\
R Square & & 0,875 \\
Adjusted R Square & & 0,866 \\
F Statistik & & 103,693 \\
Signifikansi & & 0,000 \\
\hline
\end{tabular}

Sumber: Data diolah 2017 
Nilai konstanta sebesar 0,269 artinya jika nilai seluruh variabel independen dianggap konstan (tidak ada perubahan) maka nilai manajemen laba sebesar 0,269. Nilai koefisien variabel beban pajak tangguhan sebesar 0,127 artinya jika nilai variabel beban pajak tangguhan mengalami kenaikan 1 persen, maka variabel manajemen laba mengalami kenaikan sebesar $12,7 \%$ dengan asumsi variabel bebas lainnya konstan. Nilai koefisien variabel dewan direksi sebesar 0,212 artinya jika nilai variabel dewan direksi mengalami kenaikan 1 persen, maka variabel manajemen laba mengalami kenaikan sebesar $21,2 \%$ dengan asumsi variabel bebas lainnya konstan. Nilai koefisien variabel dewan komisaris independen sebesar 0,142 artinya jika nilai variabel dewan direksi mengalami kenaikan 1 persen, maka variabel manajemen laba mengalami kenaikan sebesar 14,2 \% dengan asumsi variabel bebas lainnya konstan.

Nilai koefisien variabel komite audit independen sebesar 0,133 artinya jika nilai variabel dewan direksi mengalami kenaikan 1 persen, maka variabel manajemen laba mengalami kenaikan sebesar $13,3 \%$ dengan asumsi variabel bebas lainnya konstan. Nilai koefisien variabel kepemilikan institusional sebesar 0,131 artinya jika nilai variabel kepemilikan institusional mengalami kenaikan 1 persen maka variabel manajemen laba mengalami kenaikan sebesar 13,1\% dengan asumsi variabel bebas lainnya konstan. Nilai koefisien variabel kepemilikan manajerial sebesar 0,236 artinya jika nilai variabel kepemilikan manajerial mengalami kenaikan 1 persen, maka variabel manajemen laba mengalami kenaikan sebesar 23,6 \% dengan asumsi variabel bebas lainnya konstan. 
Berdasarkan Tabel 2 diketahui bahwa nilai adjusted $\mathrm{R}^{2}$ sebesar 0,866 mempunyai arti bahwa sebesar $86,6 \%$ variasi manajemen laba dipengaruhi oleh variasi beban pajak tangguhan, dewan direksi, dewan komisaris independen, komite audit, kepemilikan institusional, dan kepemilikan manajerial, sedangkan sisanya sebesar 13,4\% djelaskan oleh faktor lain yang tidak dimasukkan ke dalam model regresi. Pengujian kelayakan model (Uji F) digunakan untuk mengetahui model yang diestimasi layak digunakan untuk model regresi. Pengujian model fit (kelayakan model) dengan uji F menunjukkan nilai 103.693 dengan probabilitas $0.000<$ nilai alpha 0.05 sehingga model regresi layak untuk diuji.

Hasil pengujian hipotesis (uji t) dapat dilihat pada Tabel 2, hasil pengujian kemudian dibandingkan dengan tingkat signifikansi menggunakan taraf nyata $(\alpha)$ sebesar 0,05. Jika nilai signifikansi $<0,05$ maka $\mathrm{H}_{0}$ ditolak dan $\mathrm{H}_{1}$ diterima maka variabel independen secara individual berpengaruh signifikan pada variabel dependen. Uji $\mathrm{t}$ dari variabel beban pajak tangguhan dengan nilai signifikansi sebesar 0,017 lebih kecil dari $\alpha=0,05$ serta nilai koefisien regresi sebesar 0,127 . Hal ini mengindikasikan bahwa beban pajak tangguhan berpengaruh positif dan signifikan pada manajemen laba, sehingga hipotesis pertama dalam penelitian ini diterima.

Hasil analisis pengaruh dewan direksi pada manajemen laba diperoleh nilai signifikansi sebesar $0,000<0,05$ dengan nilai koefisien regresi sebesar 0,212 . Hasil ini mempunyai arti bahwa dewan direksi berpengaruh positif signifikan pada manajemen laba. Berdasarkan hasil analisis pengaruh dewan komisaris independen pada manajemen laba diperoleh nilai signifikansi sebesar $0,003<0,05$ dengan nilai koefisien regresi sebesar 0,142, artinya bahwa dewan komisaris 
berpengaruh positif signifikan pada manajemen laba. Pengaruh komite audit independen pada manajemen laba diperoleh nilai signifikansi sebesar $0,003<0,05$ dengan nilai koefisien regresi sebesar 0,133, artinya bahwa komite audit berpengaruh positif signifikan pada manajemen laba. Kepemilikan institusioal pada manajemen laba diperoleh nilai signifikansi sebesar $0,002<0,05$ dengan nilai koefisien regresi sebesar 0,131. Hasil ini mempunyai arti bahwa kepemilikan institusional berpengaruh positif signifikan pada manajemen laba. Pengaruh kepemilikan manajerial pada manajemen laba diperoleh nilai signifikansi sebesar $0,000<0,05$ dengan nilai koefisien regresi sebesar 0,236, artinya bahwa kepemilikan manajerial berpengaruh positif signifikan pada manajemen laba.

Pendeteksian manajemen laba yang dilakukan oleh manajemen perusahaan salah satunya dapat menggunakan pendekatan beban pajak tangguhan. Hasil penelitian ini mendukung penelitian dari Phillips et al. (2003) yang mengungkapkan besarnya diskresi manajemen dilihat dari besarnya perbedaan antara laba fiskal dengan laba akuntansi, yang terefleksikan dalam beban pajak tangguhan yang dapat digunakan mendeteksi tindakan manajemen laba pada perusahaan. Selain itu juga mendukung penelitian Negara (2013), Lukman (2013), Yulianti (2005), ulfah (2013), dan Budiman (2013) yang menemukan beban pajak tangguhan memiliki pengaruh positif terhadap manajemen laba, artinya nilai beban pajak tangguhan yang semakin tinggi akan mengakibatkan probabilitas perusahaan yang melakukan manajemen laba juga semakin tinggi.

Pengaruh dewan direksi yaitu positif signifikan pada manajemen laba, hal ini berarti semakin semakin banyaknya jumlah dewan direksi semakin tinggi pula 
I Wayan Andika dan I G.A.M. Asri Dwija Putri Pengaruh ...

manajemen laba yang diukur dengan tingkat discretionary accrual. Hasil Penelitian ini tidak mendukung penelitian dari Chtourou (2001) yang menyatakan dewan direksi pengaruhnya negatif pada manajemen laba. Dimana dewan direksi yang memiliki tugas dan mandat yang jelas dapat meminimalisir tindakan manajemen laba.

Hasil penelitian ini sejalan dengan Iqbal (2016) yang menemukan ukuran atau jumlah dewan direksi berpengaruh positif signifikan pada manajemen laba, ukuran dewan direksi yang kecil lebih efektif dalam menjalankan fungsi pengawasannya atas laporan keuangan, yang mamapu meminimalisir kesempatan manajer untuk memanipulasi laba. Teori akuntansi positif mengasumsikan manajer bersifat rasional, sehingga manajemen memiliki fleksibilitas untuk memilih kebijakan akuntansi yang dapat menguntungkan pihak manajemen. Salah satu hipotesis dari teri akuntansi positif terkait dengan pemilihan kebijakan akuntansi oleh manajer yaitu the bonus plan hypothesis. Manajer dengan program insentif atau bonus ini, cenderung memilih prosedur akuntansi yang mengalihkan laba di masa depan ke periode saat ini.

Penelitian ini mendukung pernyataan dari Xie, Biao (2003), perusahaan tertentu memberikan kompensasi kepada manajer atas kinerjanya baik secara langsung dalam hal gaji dan bonus atau secara tidak langsung seperti prestise, promosi masa depan dan keamanan kerja. Selain kinerja manajemen terlihat bagus, manajemen laba juga dapat meningkatkan nilai perusahaan. Abbadi (2016) menyatakan bahwa manajemen laba dapat dilakukan dengan memilih kebijakan akuntansi yang menaikkan pendapatan untuk menyembunyikan kinerja yang 
buruk. Hipotesis kos politik (political cost hypotesis) juga menyatakan bahwa semakin besar biaya politik yang dihadapi suatu perusahaan maka manajer cenderung untuk menangguhkan laba berjalan ke masa mendatang sehingga dapat memperkecil laba yang dilaporkan. Motivasi penghematan pajak juga merupakan motivasi manajemen laba yang paling nyata. Berbagai metode akuntansi digunakan dengan tujuan untuk penghematan pajak pendapatan. Mulyadi (2015) menyatakan kewajiban pajak perusahaan diminimalkan dengan menerapkan manajemen laba biasanya.

Dewan komisaris independen memiliki pengaruh positif signifikan pada manajemen laba. Namun arahnya tidak mendukung penelitian Sari dan Putri (2014), Chtourou, et al. (2001), Reviani (2012) dan dengan konsep yang dijelaskan dalam hipotesis bahwa adanya dewan komisaris independen diharapkan dapat menjadi pengawas dalam pelaksanaan tugas manajemen dan pengelolaan perusahaan, yang dapat mengurangi tindakan mementingkan diri oleh manajer dengan melakukan manajemen laba.

Temuan ini konsisten dengan hasil penelitian Putri (2012), Ujiyanto (2007) dan Boediono (2005) yang menemukan hubungan positif dewan komisaris independen dengan manajemen laba yang berarti semakin besar keanggotaan dewan komisaris independen akan semakin meningatkan tindakan manajemen laba. Menurut Boediono (2005) hal ini terjadi karena adanya kemungkinan penambahan dan penempatan anggota dewan komisaris independen oleh perusahaan dimungkinkan untuk sekedar memenuhi syarat formal, peranan 
penting masih dipegang oleh pemegang saham mayoritas (pengendali/founders) sehingga kinerja dewan tidak meningkat bahkan turun.

Kondisi ini juga ditegaskan dari hasil survai Asian Development Bank dalam Boediono (2005) yang menyatakan fungsi pengawasan yang seharusnya menjadi tanggungjawab anggota dewan menjadi tidak efektif karena masih kuatnya kendali pendiri perusahaan dan kepemilikan saham mayoritas menjadikan dewan komisaris tidak independen. Sylvia dan Siddharta (2005) menyatakan pengangkatan dewan komisaris independen oleh tidak dimaksudkan untuk menegakkan Good Corporate Governance (GCG) di dalam perusahaan namun mungkin hanya untuk pemenuhan regulasi saja.

Komite audit independen berpengaruh positif signifikan pada manajemen laba. Temuan arah penelitian ini positif sehingga tidak sesuai dengan penelitian dari Sari dan Putri (2014), Chtourou dan Jean (2001), Sirait (2014), Klien (2002) yang menemukan komite audit berpengaruh negatif pada manajemen laba. Penelitian ini sejalan dengan Igbal (2016) yang menemukan komite audit berpengaruh positif signifikan pada manajemen laba, hal ini diduga bahwa pasar akan menilai positif perusahaan ketika memiliki komite audit, karena pasar merasa manajemen laba salah satu motivasi melakukan peningkatan laba. Veronica (2005) juga menemukan interaksi antara discretionary accrual dan komite audit yaitu berhubungan secara positif dan signifikan dengan retum, hal ini menunjukkan perilaku manajemen laba pada perusahaan dirasa akan meningkatkan return oleh pasar yang memiliki komite audit. 
Salah satu pemahaman Scott (2006) mengenai manajemen laba yaitu memandang manajemen laba dari perspektif efficient contracting (efficient earnings management), yaitu manajemen melindungi dirinya dan perusahaan dalam megantisipasi kejadian yang tidak terduga untuk keuntungan pihak yang terlibat dalam kontrak dengan fleksibilitas manajemen melakukan manajemen laba. Untuk melindungi perusahaan manajer dapat melakukan manajemen laba supaya nilai perusahaannya juga meningkat.

Jumlah komite audit yang terlalu besar tidak sepenuhnya memperketat sistem pengawasan komite audit pada manajemen, karena sulit berkoordinasi dan berkomunikasi. Hal tersebut membuat peran komite audit kurang maksimal dalam menjalankan fungsi pengendalian dan pengawasan terhadap manajemen perusahaan sehingga timbul kesempatan manajemen melakukan tindakan manajemen laba (Zeptian, 2013).

Kepemilikan institusional memiliki pengaruh pada manajemen laba. Namun, temuan arah positif ini sama dengan pengembangan hipotesis dan penelitian dari Mahadewi (2017) yang menemukan kepemilikan institusional berpengaruh negatif terhadap manajemen laba. Kepemilikan institusional mampu memberikan peningkatan pengawasan lebih optimal. Penelitian ini mendukung hasil penelitian dari Sari (2014) bahwa kepemilikan institusi berpengaruh positif pada manajemen laba. Konsep dari Porter (dalam Pranata dan Mas'ud 2003) mengatakan bahwa institusional merupakan pemilik dimana lebih fokus pada current Earnings. Hal ini mengakibatkan manajer terpaksa untuk melakukan tindakan manipulasi laba yang dapat meningkatkan laba jangka pendek. Cornett et 
al. (dalam Ujiantho dan Pramuka, 2007) menyatakan kepemilikan institusional cenderung terlibat dalam manipulasi laba mengingat pihak manajer memiliki ikatan untuk memenuhi target laba dari pihak pemegang saham. Emiten yang memiliki struktur kepemilikan terfokuskan pada suatu institusi yang memiliki saham cukup besar mengindikasikan mempunyai kekuasaan tinggi sehingga memiliki kekuatan melakukan intervensi terhadap jalannya perusahaan dan mengatur proses penyusunan laporan keuangan. Sehingga dalam hal ini, tindakan manipulasi laba terpaksa dilakukan untuk memenuhi keinginan pihak-pihak tertentu.

Kepemilikan manajerial berpengaruh pada manajemen laba. Namun, ditemukan arah positif yang tidak sama dengan konsep hipotesis dan penelitian dari Sari (2014), Mahariana (2014) dan Kusumawardani (2012) yang menemukan kepemilikan manajerial berpengaruh negatif signifikan terhadap manajemen laba yang menunjukkan kepemilikan manajerial mampu menurunkan tindakan manajemen laba. Namun, hasil penelitian ini konsisten dengan temuan dari Wiryadi (2013) dan Sari (2014) yang menemukan kepemilikan manajerial berpengaruh positif pada manajemen laba. Pihak manajer diperusahaan yangmemiliki saham tentu ada kemauan untuk kepentingan pribadinya seperti memperoleh return dari presentase saham yang dimilikinya.

Pihak manajemen punya keleluasaan dan probabilitas untuk bertindak memanipulasi laba baik itu menaikkan laba ataupun menurunkan labanya. Ini terjadi karena ada asimetri informasi yaitu kondisi karena salah satu pihak memiliki kelebihan informasi yaitu manajemen. Sehingga kepemilikan saham 
oleh manajemen yang tinggi, dapat meningkatkan probabilitasnya dalam melakukan manajemen laba. Adanya kepemilikan seorang manajerial, maka mereka akan ikut memilih kebijakan, mengambil keputusan terhadap metode akuntasi yang diterapkan di perusahaan yang dikelolanya, sehingga dapat meentukan terjadinya tindakan manipulasi laba (Boediono, 2005).

\section{SIMPULAN}

Berdasarkan hasil penelitian yang diperoleh melalui pengujian statistik serta pembahasan, maka dapat disimpulkan bahwa beban pajak tangguhan berpengaruh positif signifikan pada manajemen laba, hal ini disebabkan beban pajak tangguhan merupakan salah satu instrumen pendeteksi manajemen laba. Nilai beban pajak tangguhan yang semakiin tinggi akan mengakibatkan profitabilitas perusahaan yang melakukan manajemen laba juga semakin tinggi. Dewan direksi mempunyai pengaruh signifikan pada manajemen laba dengan arahnya positif, jumlah dewan direksi yang sedikit akan lebih efektif dalam menjalankan fungsi pengawasannya pada laporan keuangan, sehingga meminimalisir kesempatan bagi manajer untuk melakukan manajemen laba. Dewan komisaris independen berpengaruh positif signifikan pada manajemen laba, semakin besar keanggotaan dewan komisaris independen akan semakin meningatkan tindakan manajemen laba.

Komite audit independen berpengaruh positif signifikan pada manajemen laba, pasar akan menilai positif perusahaan ketika memiliki komite audit, karena pasar merasa manajemen laba salah satu motivasi melakukan peningkatan laba. Kepemilikan institusional berpengaruh signifikan pada manajemen laba dengan arah positif, hal ini disebabkan karena kepemilikan saham yang besar oleh 
institusional memiliki kekuasaan yang besar sehingga dapat mengintervensi pihak manajemen dalam proses jalannya perusahaan dan mengatur pelaporan keuangan perusahaan. Kepemilikan manajerial berpengaruh signifikan pada manajemen laba dengan arah positif. Seorang manajer yang juga mempunyai saham ada keinginan untuk memenuhi kepentingan pribadinya seperti return yang diterima dari kepemilikan saham pada perusahaan.

Saran yang dapat diberikan adalah bagi perusahaan sebaiknya menghindari praktek manajemen laba dan mengoptimalkan penerapan mekanisme pengelolaan perusahaan agar tercipta suatu kondisi perusahaan yang baik atau good corporate governance. Para investor dan calon investor diharapkan berhati-hati dala mengambil keputusan untuk berinvestasi dan mampu menyimak laporan keuangan yang dipublikasikan perusahaan setiap tahunnya dan menyimak juga laporan nonkeuangan. Penelitian selanjutnya dapat memperluas objek penelitian baik dari segi bidang usaha, periode penelitian dan menguji variabel lain yang menjadi motif perusahaaan melakukan praktek manajemen laba seperti penghindaran pajak, perencanaan pajak. Keterbatasan penelitian ini menggunakan proksi corporate governance seperti dewan direksi, dewan komisaris independen, komite audit independen, kepemilikan institusional dan kepemilikan manajerial, penelitian selanjutnya dapat menggunakan analisis faktor untuk menentukan proksi yang paling berpengaruh pada manajemen laba. Penelitian ini hanya mengambil periode empat tahun sehingga dirasa belum akurat. 


\section{REFERENSI}

Abbadi, Sinan S., Qutaiba F. Hijazi, and Ayat S. Al-Rahahleh. 2016. Corporate governance quality and earnings management: Evidence from Jordan. Australasian Accounting Business \& Finance Journal 10(2), hal, 54

Al-Hafi, Lama M. 2016. Effects of corporate governance on earnings management.(c2016). Diss. Lebanese American University.

Alzoubi, E. S. S., \& Selamat, M. H. 2012. The effectiveness of corporate governance mechanisms on constraining earning management: Literature review and proposed framework. International Journal of Global Business, 5(1), 17-35.

Amanda, F., \& Febrianti, M. 2015. Analisis Pengaruh Beban Pajak Kini, Beban Pajak Tangguhan, dan Basis Akrual Terhadap Manajemen Laba. Ultima Accounting, 7(1), 70-86.

Barus, A. C. \& Setiawti, K. 2015. Pengaruh Asimetri Informasi, Mekanisme Corporate Governance dan Beban Pajak Tangguhan Terhadap Manajemen Laba. JWEM (Jurnal Wira Ekonomi Mikroskil), 5(1), 31-40.

Boediono, Gideon S.B. 2005. Kualitas Laba: Studi Pengaruh Mekanisme Corporate Governance dan Dampak Manajemen Laba dengan Menggunakan Analisis Jalur. Prosiding Simposium Nasional Akuntansi 8 Solo.

Budiman, T. 2014. Pengaruh Beban Pajak Tangguhan dan Akrual terhadap indikasi adanya praktik Manajemen Laba. Fakultas Ekonomi Universitas Komputer Indonesia.

Chtourou, Sonda Marrakchi, Jean Bedard, and Lucie Courteau. 2001. Corporate governance and earnings management. www.ssrn.com

Dechow, Patricia M., Richard G. Sloan, and Amy P. Sweeney. 1995. Detecting Earnings Management. The Accounting Review, 70 (2), pp: 193-225.

Healy, P.M. 1985. The Effect of Bonus Scheme on Accounting Decisions. Journal of Accounting and Economics. 7: 85-107.

Iqbal, S., \& Fachriyah, N. 2016. Corporate governance sebagai alat pereda praktik manajemen laba (earnings management). Jurnal TEMA, 8(1).

Islam, Md. Aminul, Ruhani Ali, and Zamri Ahmad. 2011. Is Modified Jones Model Effective in Detecting Earnings Management? Evidence from a Developing Economy. International Journal of Economics and Finance, 3 (2), pp: 116-125.

Jensen. M.C. dan W.H. Meckling. 1976. Theory of The Firm :Managerial Behavior Agency Cost and Ownership Structure. Journal of Financial Economics 3(4):305-360. 
.KNKG. 2006. Pedoman Umum Good Corporate Governance Indonesia. Jakarta

Kusumawardhani, Indra. 2012. Pengaruh Corporate Governance, Struktur Kepemiliikan, dan Ukuran Perusahaan terhaidap Manajemen Laba. Jurnal Akuntansi dan Sistem Teknologi Informasi, 9(1), hal. 41-54.

Klein, April. 2002. Audit committee, board of director characteristic, and earnings management. Journal of accounting and economics, 33 (3). hal 375-400.

Lukman, Pungky. 2013. Kemampuan Beban Pajak Tangguhan dalam Memprediksi Ukuran Manajemen Laba. Semarang: Universitas Diponegoro.

Man, Chi-keung, and Brossa Wong. 2013. Corporate governance and earnings management: A survey. Journal of Applied Business Research. 29 (2), hal 391.

Mahariana, I Dewa Gede Pingga, Dan I Wayan Ramantha. 2014. Pengaruh Kepemilikan Manajerial dan Kepemilikan Institusional pada Manajemen Laba Perusahaan Manufaktur Di Bursa Efek Indonesia. E-Jurnal Akuntansi Universitas Udayana, 7 (2), hal. 519-528.

Mahadewi, A.A Istri Sri Dan Komang Ayu Krisnadewi. 2017. Pengaruh Kepemilikan Manajerial, Institusional Dan Proporsi Dewan Komisaris Independen Pada Manajemen Laba. E-Jurnal Akuntansi Universitas Udayana, 18 (1), hal. 443-470.

Mulyadi, M. S., \& Anwar, Y. 2015. Corporate governance, earnings management and tax management. Procedia-Social and Behavioral Sciences, 177, 363366.

Negara, A. G. R. P., \& Suputra, I. D. 2017. Pengaruh perencanaan pajak dan beban pajak tangguhann terhadap manajemen laba. E-Jurnal Akuntansi, 2045-2072

Oktaviani, H. D. 2016. Pengaruh Ukuran Dewan Diireksi, Proporsi Dewan Komisaris Independen, Dan Ukuran Komite Audit Terhadap Praktik Manajemen Laba Pada Perusahaan Farmasi Yang Terdaftar Di Bei Tahun 2009-2014. Jurnal Akuntansi Unesa, 4(2).

Phillips, John., M. Pincus and S. Rego,. 2003. "Earnings Management: New Evidence Base on Deferred Tax Expense". The Accounting Review, Vol 78.

Prabaningrat, I G. A. A \& Widanaputra, A.A. GP. 2015. Pengaruh Good Corporate Governance Dan Konservatisme Akuntansi Pada Manajemen Laba. E-Jurnal Akuntansi: 10 (3), hal. 663-676.

Prastiti, A., \& Meiranto, W. 2013. Pengaruh karakteristik dewan komisaris dan komite audit terhadap manajemen laba (Doctoral dissertation, Fakultas Ekonomika dan Bisnis). 
Pranata, Puspa Midiastuty dan Mas'ud Mahfoedz. 2003. "Analisis Hubungan Mekanisme Corporate Governance dan Indikasi Manajemen Laba." Simposium Nasional Akuntansi VI. IAI, Surabaya.

Putri, I G. A. M. A. D. 2012. Pengaruh Kebijakan Dividen Dan Good Corporate Governance Terhadap Manajemen Laba. Buletin Studi Ekonomi, 17(2), hal. $157-171$.

Rahadi, H. P. 2014. Pengaruh Mekanisme Good Corporate Governance Terhadap Praktik Manajemen Laba Di Bursa Efek Indonesia. Jurnal Ilmu dan Riset Akuntansi, 3(10).

Reviani, Dinni, and Djoko Sudantoko. 2012. Pengaruh struktur kepemilikan, ukuran perusahaan, dan corporate governance terhadap manajemen laba. 9 (1), hal. 92-108.

Saraswati, Riski, Sulistyo Sulistyo, and Rita Indah Mustikowati. 2016. Pengaruh Good Corporate Governance dan Financial Distress Terhadap Manajemen Laba (Studi Kasus pada Perbankan yang Listing di Bursa Efek Indonesia Periode 2011-2014). Jurnal Riset Mahasiswa Akuntansi. 4 (1).

Sari, A.A Intan Puspita, and I. G.A.M Asri Dwija Putri. 2014. Pengaruh Mekanisme Corporate Governance Pada Manajemen Laba. E-Jurnal Akuntansi:8 (1), hal 94-104.

Sari, Dewi Arum, Edyanus Herman Halim, and Ahmad Fauzan Fathoni. 2014. Pengaruh mekanisme good corporate governance dan financial distress terhadap earning management (Studi empiris pada perusahaan manufaktur yang terdaftar di Bursa Efek Indonesia)." Jurnal Online Mahasiswa (JOM) Bidang Ilmu Ekonomi 1 (1), hal, 1-15.

Sylvia Veronica N.P. Siregar dan Siddharta Utama. 2005. Pengaruh Struktur Kepemilikan, Ukuran Perusahaan, dan Praktek Corporate Governance Terhadap Pengelolaan Laba (Earnings Management). Simposium Nasional Akuntansi VIII, IAI.

Suandy, Erly. 2011. Perencanaan Pajak. Jakarta: Salemba 4.

Sugiyono. 2014. Metode Penelitian Bisnis. Bandung: Alfabeta.

Susanto, Sherly dan Christiawan, Yulius Jogi. 2016. Pengaruh Earnings Management terhadap Firm Value. Business Accounting Review, 4 (1), pp: 205-216.

Tundjung, G. M. M., \& Haryanto, H. 2015. Pengaruh Beban Pajak Tangguhan Terhadap Manajemen Laba (Studi Empiris Pada Perusahaan Manufaktur Yang Terdaftar Di Bursa Efek Indonesia) (Doctoral Dissertation, Fakultas Ekonomika Dan Bisnis).

Ujiyantho, M. A., \& Pramuka, B. A. 2007. Mekanisme Corporate Governance, Manajemen Laba dan Kinerja Keuangan. Simposium Nasional Akuntansi 
$X, 26-28$.

Ulfah, Y. 2013. Pengaruh Beban Pajak Tangguhan dan Perencanaan Pajak Terhadap Praktik Manajemen Laba. Prosiding Simposium Nasional Perpajakan, 4.

Uwuigbe, U., Sunday, D., \& Oyeniyi, A. 2014. The Effects Of Corporate Governance Mechanisms On Earnings Management Of Listed Firms In Nigeria Abstract :, 13(1), 159-174.

Veronica, S., \& Bachtiar, Y. S. 2005. Corporate governance, information asymmetry, and earnings management. Jurnal Akuntansi dan Keuangan Indonesia, 2(1), 77-106.

Wiranata, Yulius Ardy dan Yeterina Widi Nugrahanti. 2013. Pengukuran Struktur Kepemilikan terhadap Profitabilitas Perusahaan Manufaktur di Indonesia. Jurnal Akuntansi dan Keuangan, 15 (1), hal. 1-16.

Wiryadi, A., \& Sebrina, N. 2013. Pengaruh Asimetri Informasi, Kualitas Audit, Dan Struktur Kepemilikan Terhadap Manajemen Laba. Wahana Riset Akuntansi, 1(2).

Xie, Biao, Wallace N. Davidson, and Peter J. DaDalt. 2003 Earnings management and corporate governance: the role of the board and the auditt committee. Journal of corporate finance 9(3), pp. 95-316

Yu, Frank. 2006. Corporate Governance and Earnings Management. Working Paper. http//:www.google.com. Diakses September 2017.

Yulianti. 2005. Kemampuan Beban Pajak Tangguhan dalam Mendeteksi Manajemen Laba. Jurnal Akuntansi dan Keuangan Indonesia, Vol. 2, No. 1: pp. 107-129.

Zeptian, A., \& Rohman, A. 2013. Analisis Pengaruh Penerapan Corporate Governance, Struktur Kepemilikan, dan Ukuran Perusahaan terhadap Manajemen Laba pada Perbankan. Diponegoro Journal of Accounting, 4757. 